Sains Malaysiana 49(6)(2020): 1389-1400

http://dx.doi.org/10.17576/jsm-2020-4906-17

\title{
Enhancing Effect of Vitexin on Osteogenic Activity of Murine Pre-Osteoblastic MC3T3-E1 Cells
}

\author{
(Kesan Peningkatan Viteksin terhadap Aktiviti Osteogenik Sel MC3T3-E1 Pra-Osteoblastik Murin)
}

\author{
Xiaohan Yuan, HaiYan Han, Zhaohui Luo, QiuXue Wang, Peijia Tang, Zhihui Zhang, Yujie Fu \& \\ CHENGBO GU*
}

\begin{abstract}
Vitexin (5,7,4-trihydroxyflavone-8-glucoside), a natural flavone present in a variety of plants, is well known for its rich pharmacological properties. However, its osteogenic activity remains unclear to date. The purpose of this study was to explore the effects of vitexin on osteogenic activity in murine pre-osteoblastic MC3T3-E1 cells using the MTT assay for cell proliferation, alkaline phosphatase (ALP) activity assay for cell differentiation, and Von Kossa staining for cell mineralization. Quantitative real-time PCR was used for the detection of osteocalcin (OCN) mRNA expression in cells. Furthermore, effects of vitexin on the differentiation and matrix mineralization of dexamethasone (DEX)suppressed cells was also investigated. The results showed vitexin could significantly enhance cell proliferation in a low concentration range of $10^{-10}-10^{-6} \mu \mathrm{g} \mathrm{mL}^{-1}$. ALP activity was significantly increased after the cells were treated with vitexin at $10^{-8}$ and $10^{-6} \mu \mathrm{g} \mathrm{mL}^{-1}$. The expression levels of the osteogenic OCN gene in cells treated with vitexin at $10^{-6}$, $10^{-}$ ${ }^{8}$, and $10^{-10} \mu \mathrm{g} \mathrm{mL^{-1 }}$ were improved by 3.1-fold, 5.8-fold, and 4.2-fold over the control, respectively. Additionally, vitexin $\left(10^{-8} \mu \mathrm{g} \mathrm{mL}^{-1}\right)$ significantly alleviated the inhibitory effect of osteoblast differentiation and mineralization induced by DEX. Collectively, our findings suggest vitexin could enhance cell proliferation and osteogenic differentiation of MC3T3-E1 cells, as well as rescue the inhibitory effect of cell differentiation and matrix mineralization induced by DEX. Therefore, vitexin may be useful as a promising therapeutic agent for bone disease and plays an important role in the prevention of glucocorticoid-induced osteoporosis.
\end{abstract}

Keywords: Anti-osteoporosis; dexamethasone; MC3T3-E1 cells; osteogenic activity; vitexin

ABSTRAK

Viteksin (5,7,4-trihidroksiflavon-8-glucosida), merupakan flavon semula jadi yang terdapat dalam pelbagai jenis tumbuhan juga terkenal dengan khasiat farmakologinya yang tinggi. Walau bagaimanapun, aktiviti osteogeniknya masih belum jelas sehingga kini. Tujuan kajian ini adalah untuk mengkaji kesan viteksin terhadap aktiviti osteogenik pada sel MC3T3-E1 pra-osteoblas murin menggunakan asai MTT untuk proliferasi sel, asai aktiviti alkali fosfatase (ALP) untuk pembezaan sel dan pewarnaan Von Kossa untuk mineralisasi sel. PCR masa nyata kuantitatif digunakan untuk mengesan ekspresi mRNA osteokalsin (OCN) dalam sel. Selanjutnya, kesan viteksin terhadap pembezaan dan mineralisasi matriks deksametason (DEX) sel yang ditindas juga dikaji. Hasil kajian menunjukkan viteksin dapat meningkatkan proliferasi sel secara signifikan dalam julat kepekatan yang rendah iaitu $10^{-10}-10^{-6} \mu \mathrm{g} \mathrm{mL}^{-1}$. Aktiviti ALP meningkat dengan ketara setelah sel dirawat dengan viteksin pada kepekatan $10^{-8}$ dan $10^{-6} \mu \mathrm{g} \mathrm{mL}^{-1}$. Tahap ekspresi gen OCN osteogenik dalam sel yang dirawat dengan viteksin pada $10^{-6}, 10^{-8}$ dan $10^{-10} \mu g \mathrm{~mL}^{-1}$ masing-masing meningkat sebanyak 3.1, 5.8 dan 4.2 kali ganda daripada kawalan. Selain itu, viteksin dengan kepekatan $10^{-8} \mu g \mathrm{~mL}^{-1}$ juga didapati meningkatkan kesan perencatan pembezaan osteoblas dan mineralisasi yang diaruh oleh DEX. Secara kolektifnya, hasil kajian ini menunjukkan bahawa viteksin dapat meningkatkan proliferasi sel dan pembezaan osteogenik sel MC3T3-E1, serta melindungi daripada kesan perencatan pembezaan osteoblas dan mineralisasi yang diaruh oleh DEX. Oleh itu, viteksin berpotensi digunakan sebagai agen terapi yang baik bagi merawat penyakit tulang dan memainkan peranan penting dalam pencegahan osteoporosis yang disebabkan oleh glukokortikoid.

Kata kunci: Aktiviti osteogenik; anti-osteoporosis; deksametason; sel MC3T3-E1; viteksin

\section{INTRODUCTION}

Osteoporosis is a systemic skeletal disease common in the aging population and post-menopausal women. It is characterized by low bone mass and micro-architectural deterioration of bone tissue, resulting from an imbalance between bone resorption and bone formation (Chen \& Sambrook 2012). This leads to an increased risk for 
fractures in patients (Pereira et al. 2012) Osteoporosis may be caused by one or more risk factors like estrogen deficiency, aging, genetic disorder, endocrine problems, malnutrition, and chronic exposure to medications and treatments, among which glucocorticoid-induced osteoporosis (GIO) is considered to be the most common secondary iatrogenic form of osteoporosis (Wu et al. 2018).

Glucocorticoids (GCs) have been extensively used in the treatment of a variety of diseases, due to their potent anti-inflammatory and immuno-suppressive effects (Balasubramanian et al. 2018; Weinstein 2011). However, the prolonged and/or overdose use of GCs is regarded as the primary cause of secondary osteoporosis (Caplan et al. 2017; Guanabens et al. 2014). Osteoblasts played an essential role in bone formation. GCs were reported to modify osteoblastic cell differentiation, number, and function (Canalis 2003). The pathogenesis of GIO includes reduced bone formation and enhanced bone resorption (Adami \& Saag 2019). GCs decreased osteoblast function and promoted apoptosis of osteoblasts and osteocytes, leading to an increased risk of fractures soon after the initiation of GCs therapy (Adler 2019; Canalis \& Delany 2002).

Available treatments for osteoporosis include hormone therapy, bisphosphonates, the selective estrogen receptor modulator (SERM), monoclonal antibodies like denosumab, calcitonin, and parathyroid hormone (Chen \& Sambrook 2012; Wang et al. 2012). Among them, hormone replacement therapy (HRT) was an effective option in both preventing postmenopausal osteoporosis and decreasing fracture incidence (Guanabens et al. 2014). However, HRT was reported to increase the risk of breast cancer, venous thromboembolism (VTE), and stroke (Bolognese 2010). Oral bisphosphonates are generally considered the first choice for the treatment of GIO (Adami \& Saag 2019), but their long-term use can increase the risk of atypical stress fractures in the femoral shaft (Chen \& Sambrook 2012). SERMs are an effective option for women who cannot tolerate or are reluctant to take bisphosphonates for fear of the long-term-use side effects (Hadji 2012). One concern related to the usage of SERMs seems to be an increased incidence of hot flushes and warrants further study to determine clinical relevance (Kulak et al. 2010). Denosumab, a bone-modifying agent, was effective for GIO in clinical trials. However, it has some safety concerns like hypocalcemia, atypical femur fractures, and osteonecrosis of the jaw (Zaheer et al. 2015). Calcitonin inhibits bone resorption by binding to osteoclasts through a high-affinity receptor. Adverse effects of calcitonin therapy include nausea or vomiting, rhinitis, stinging or tingling of the nasal passages, and sneezing. The role of parathyroid hormone (PTH) as an anabolic agent in treating osteoporosis is generally accepted, but concerns have been raised about PTH (1-34) side effects like hypercalcemia and tumor risk (Ponnapakkam et al. 2014). Currently, for the prevention and treatment of osteoporosis, the agents are limited to co-prescription of calcium and vitamin $\mathrm{D}$ (Chen et al. 2014). Therefore, novel therapeutic strategies with minimal adverse effects are desperately needed.

Vitexin (5, 7, 4-trihydroxyflavone-8-glucoside), is a natural C-glycosylated flavone that is present in Cajanus cajan, Crataegus pinnatifida, Acer palmatum, and other plants ( $\mathrm{Gu}$ et al. 2017; Kim et al. 2005). Vitexin recently gained considerable attention because of its rich pharmacological properties, including antioxidant, anti-inflammatory, anti-hypotensive, anti-cancer, anti-spasmodic, antimicrobial, antithyroid and antiarteriosclerotic effects (Dong et al. 2011; He et al. 2016; Prabhakar et al. 1981). Recently, a traditional medicine made of a water extract of Cajanus cajan leaves was approved for clinical use by the State Food and Drug Administration in China, and displays a remarkable preventive effect on steroid-induced avascular necrosis of the femoral head (Zhang et al. 2010). Vitexin is considered one of the major active ingredients in $C$. cajan leaves ( $\mathrm{Fu}$ et al. 2007). As a result, we hypothesized that vitexin may possess protective effects against osteoporosis. To the best of our knowledge, the osteogenic activity of vitexin remains unclear to date.

The purpose of the present study was to evaluate the effects of vitexin on osteogenic activity in murine pre-osteoblastic MC3T3-E1 cells using the 3-(4,5-dimethylthiazol-2-yl)-2,5-diphenyl-tetrazolium bromide (MTT) assay for cell proliferation, alkaline phosphatase (ALP) activity assay for cell differentiation, and Von Kossa staining for the assay of mineralized bone nodule formation of osteoblast cells. Quantitative real-time PCR is used for the detection of the expression of osteocalcin (OCN) mRNA in cells. Furthermore, the effect of vitexin on the differentiation and matrix mineralization of dexamethasone (DEX)-suppressed cells was also investigated.

\section{MATERIALS AND METHODS}

Vitexin, 17- $\beta$-estradiol (E2), dimethylsulfoxide (DMSO), MTT, dexamethasone (DEX), and trypsin were purchased from Sigma Chemical Co. (St. Louis, MO, USA). Fetal bovine serum (FBS), alpha-minimum essential medium $(\alpha$-MEM), and penicillin-streptomycin antibiotic mixture were obtained from Hyclone (Hyclone, Logan, UT, USA). An alkaline phosphatase (ALP) activity kit was obtained from the Nanjing Jiancheng Biological Engineering Institute (Nanjing, China). A protein assay kit was purchased from Bio Rad. Trizol, and SuperScript ${ }^{\circledR}$ III Reverse Transcriptase was purchased from Invitrogen (Invitrogen, San Diego, CA, USA). A SYBR green kit for RT-PCRs was obtained from TaKaRa Biotech Co. (TaKaRa, Dalian, China), and Trizol reagent was obtained from Invitrogen Corporation (Carlsbad, CA, USA). Vitexin and E2 were dissolved in DMSO to make stock solutions, which were further diluted to different working concentrations with the medium before use. 


\section{CELL CULTURE}

Murine pre-osteoblastic MC3T3-E1 cells were purchased from China Center for Type Culture Collection (CCTCC) (Wuhan, China) and cultured in a growth medium consisting of $\alpha$-MEM supplemented with $10 \%$ FBS and $1 \%$ penicillin-streptomycin (Hyclone, USA) at $37{ }^{\circ} \mathrm{C}$ in a humidified atmosphere containing $5 \% \mathrm{CO}_{2}$. For the induction of cell differentiation of MC3T3-E1 cells into mature osteoblastic cells, the growth culture medium was supplemented with $10 \mathrm{mM} \beta$-glycerophosphate and $50 \mu \mathrm{g} \mathrm{mL}^{-1}$ ascorbic acid as osteogenic medium.

\section{CELL PROLIFERATION ASSAY}

Cell proliferation was determined using MTT assay. MC3T3-E1 cells were plated at a density of $5 \times 10^{4}$ cells/well in 96-well plates. After overnight incubation, the cells were washed twice with PBS solution, and then treated with low-concentration vitexin $\left(10^{-6}-10^{-10} \mu \mathrm{g}\right.$ $\left.\mathrm{mL}^{-1}\right)$ and E2 $\left(10^{-8} \mu \mathrm{g} \mathrm{mL}^{-1}\right.$ of E2 was chosen as positive control) for $24 \mathrm{~h}$. Vitexin and E2 were dissolved in DMSO at a concentration of $10 \mathrm{mg} \mathrm{mL}^{-1}$ stock solution and diluted in the culture medium to the working solution before use. To avoid DMSO toxicity, the concentration of the solvent was less than $0.1 \%(\mathrm{v} / \mathrm{v})$. Cells treated with the growth medium contained $0.1 \%$ DMSO were used as control, and wells without cells were set as blanks. E2 was used as positive control. After the exposure period, $20 \mu \mathrm{L}$ of $5.0 \mathrm{mg} \mathrm{mL}^{-1}$ MTT was added to each well and further incubated at $37^{\circ} \mathrm{C}$. After $4 \mathrm{~h}$, the supernatant was discarded and $150 \mu \mathrm{L}$ of DMSO was added to solubilize the dark blue formazan crystals at $37^{\circ} \mathrm{C}$. After $15 \mathrm{~min}$, the absorbance value (OD) was measured on a microplate spectrophotometer (Bio-Rad Model 680, Hercules, CA, USA) at $490 \mathrm{~nm}$. The cell proliferation rate was represented as the percentage of the OD of samples to that of the control group.

\section{CELL DIFFERENTIATION}

MC3T3-E1 cells were seeded in 12-well plates at a density of $5 \times 10^{4}$ cells/well and were allowed to reach $80 \%$ confluence. The culture medium was then changed to $\alpha$-MEM plus $5 \%$ FBS medium containing various concentrations of vitexin $\left(10^{-6}, 10^{-8}\right.$ and $\left.10^{-10} \mu \mathrm{g} \mathrm{mL}^{-1}\right)$ or with E2 $\left(10^{-8} \mu \mathrm{g} \mathrm{mL}^{-1}\right)$ as a positive control. The ALP assay for osteoblasts differentiation was performed on the 5th day of the culture. Cells treated with the growth medium contained $0.1 \%$ DMSO were used as the control, and wells without cells were set as blanks. On the indicated day of the culture, the medium was discarded and the cell monolayer was gently washed three times by ice-cold PBS and lysed on ice for $30 \mathrm{~min}$ with $100 \mu \mathrm{L}$ of lysis buffer $(0.2 \%$ Triton $\mathrm{X}-100)$. The lysate was centrifuged at $12,000 \mathrm{rpm}$ for $5 \mathrm{~min}$. The clear supernatant was collected for the assay of ALP activity using the ALP Assay kit (Nanjing Jiancheng Bioengineering Ltd.). The protein concentration of the cell lysate was determined by the protein assay kit.

\section{QUALITATIVE REAL-TIME PCR}

The cells were seeded in 6-well plates at a density of 2 $\times 10^{5}$ cells $\mathrm{mL}^{-1}$ and cultured in MEM containing $10 \%$ FBS until they reached $80 \%$ confluence. The cells were then stimulated with different concentrations of vitexin $\left(10^{-10}, 10^{-8}\right.$ and $\left.10^{-6} \mu \mathrm{g} \mathrm{mL} \mathrm{mL}^{-1}\right)$ and E2 $\left(10^{-8} \mu \mathrm{g} \mathrm{mL} L^{-1}\right.$ as a positive control for $96 \mathrm{~h}$. At the end of the treatment time, the cells were collected and the total RNA was extracted using Trizol reagent. Reverse transcription of total RNA was performed for $50 \mathrm{~min}$ at $42{ }^{\circ} \mathrm{C}$ and then $15 \mathrm{~min}$ at $70{ }^{\circ} \mathrm{C}$, using SuperScript ${ }^{\circledR}$ III Reverse Transcriptase (Invitrogen, USA). Following cDNA synthesis, quantitative RT-PCR was performed on an ABI 7500 Real-Time PCR System (Applied Biosystems Foster City, CA, USA) with SYBR Premix Ex TaqTM II in accordance with the manufacturer's instructions. The mRNA value for the $O C N$ gene was normalized relative to the mouse GAPDH mRNA level in the RNA sample. The primers were designed as follows: $O C N$ (forward primer, 5'-TGGCTTCTCTCCCTACTCCA-3'; reverse primer, 5'-GCAGCTGCAAAATCTCCTC-3'), GAPDH (forward primer, 5'-TCACCATCTTCCAGGAGCGA-3'; and reverse primer, 5'-CACAATGCCGAAGTGGTGGT-3'). The PCR conditions were $95{ }^{\circ} \mathrm{C}$ for $3 \mathrm{~min}$ followed by $95^{\circ} \mathrm{C}$ for $30 \mathrm{~s}$ and $58^{\circ} \mathrm{C}$ for $40 \mathrm{~s}$ for a total of 35 cycles. All the reactions were run in triplicate and the results were analyzed by the $2^{-\Delta \Delta C \mathrm{~T}}$ method.

\section{DETERMINATION OF THE INHIBITORY CONCENTRATION OF DEX ON MC3T3-E1 CELLS}

A determination of the inhibitory concentration of DEX in MC3T3-E1 cells was done using the MTT assay. MC3T3-E1 cells $\left(5 \times 10^{4} /\right.$ well $)$ were seeded in 96-well plates, incubated overnight and then treated with DEX at various concentrations of $10^{-9}-10^{-5} \mu \mathrm{g} \mathrm{mL}-1$ for $24 \mathrm{~h}$. After the exposure period, the absorbance values at 490 $\mathrm{nm}$ were measured on a microplate spectrophotometer and the effects of various concentrations of DEX on cell proliferation were evaluated by the MTT method described previously.

\section{EFFECT OF VITEXIN ON DEX-EXPOSED CELL ALP ACTIVITY}

The MC3T3-E1 cells were seeded in 12-well culture plates at $5 \times 10^{4}$ cells/well and cultured with $\alpha$-medium with $10 \%$ FBS in the presence or absence of $10^{-6} \mathrm{M}$ DEX. After $24 \mathrm{~h}$ of culture, the cells cultured in the 12 well plates were divided into four groups: The control group, where the DEX-unexposed cells were treated with $\alpha$-MEM supplemented with $10 \%$ FBS; the DEX group, where the DEX-pretreated cells were incubated with $\alpha$-medium with $10 \%$ FBS; the DEX+vitexin group, where the DEX-pretreated cells were incubated with $10^{-8}$ 
$\mu \mathrm{g} \mathrm{mL}^{-1}$ of vitexin; and the DEX+E2 group, where the DEX-pretreated cells were incubated with $10^{-8} \mu \mathrm{g} \mathrm{mL}^{-1}$ of E2. After 3 days of treatment, ALP activities of cells in different groups were measured by the method described previously. Every treatment was made in triplicate.

\section{EFFECT OF VITEXIN ON DEX-EXPOSED OSTEOBLAST MATRIX MINERALIZATION}

MC3T3-E1 cells were seeded in 6-well plates at a density of $5 \times 10^{4}$ cells/well and cultured with a differentiation medium ( $\alpha$-MEM with $10 \%$ FBS, $10 \mathrm{mM} \beta$-glycerophosphate, and $50 \mu \mathrm{g} \mathrm{mL}^{-1}$ ascorbic acid) in the presence or absence of $10^{-6} \mathrm{M}$ DEX. After a $24 \mathrm{~h}$ incubation, the cells cultured in the 6-well plates were divided into four groups: The control group, where the DEX-unexposed cells were treated with $\alpha$-MEM supplemented with $10 \%$ FBS; the DEX group, where the DEX-pretreated cells were incubated with $\alpha$-medium with $10 \%$ FBS; the DEX+vitexin group, where the DEXpretreated cells were incubated with $10^{-8} \mu \mathrm{g} \mathrm{\textrm {mL } ^ { - 1 }}$ of vitexin containing a-MEM with $10 \% \mathrm{FBS}$; and the $\mathrm{DEX}+\mathrm{E} 2$ group, where the DEX-pretreated cells were incubated with $10^{-8} \mu \mathrm{g} \mathrm{mL} \mathrm{m}^{-1}$ of E2. The medium was changed every 2 days. After 28 days of treatment, the formation of mineralized matrix nodules in different groups was evaluated using Von Kossa staining. In brief, the cells were rinsed twice with cold saline and were fixed with $4 \%$ formaldehyde at $4{ }^{\circ} \mathrm{C}$ for $30 \mathrm{~min}$. The fixed cells were then rinsed twice with saline, followed by an addition of $5 \%(\mathrm{w} / \mathrm{v})$ silver nitrate solution and a subsequent exposure to UV-light for $1 \mathrm{~h}$. The cells were then stained with $5 \%(\mathrm{w} / \mathrm{v})$ sodium thiosulfate solution for $5 \mathrm{~min}$ and counterstained with natural red. The presence of mineralized calcium deposits was qualitatively confirmed by brownish-black color staining, which was readily observable under bright-field light microscopy. A quantitative assessment of Von Kossa staining was made by the counting of stained nodules.

\section{STATISTICAL ANALYSIS}

Statistical significances were performed using SPSS version 16.0 (IBM Corp, NY, USA). Data were expressed as the mean \pm standard deviation (SD) of three parallel measurements. A one-way analysis of variance was performed, followed by a Least-significant difference (LSD) test for multiple comparisons if necessary. In all cases, $\mathrm{p}<0.05$ was considered as significant, $\mathrm{p}<0.01$ was considered as highly significant.

RESULTS

\section{EFFECT OF VITEXIN ON MC3T3-E1 CELL PROLIFERATION}

As shown in Figure 1, the effect of vitexin at various concentrations of $10^{-10}-10^{-6} \mu \mathrm{g} \mathrm{mL}^{-1}$ on MC3T3-E1 cell proliferation was significant $(\mathrm{p}<0.05$ or $\mathrm{p}<0.01)$ at $48 \mathrm{~h}$. The maximum stimulatory effect on cell proliferation was achieved at $48 \mathrm{~h}$ when vitexin was at a concentration of $10^{-8} \mu \mathrm{g} \mathrm{mL}^{-1}$. As a positive control, 17- $\beta$-estradiol (E2) at $10^{-8} \mu \mathrm{g} \mathrm{mL} \mathrm{m}^{-1}$ was also found to significantly stimulate cell proliferation at $48 \mathrm{~h}(\mathrm{p}<0.01)$. However, the cell proliferation rate was higher in the groups treated with vitexin $\left(10^{-8} \mu \mathrm{g} \mathrm{mL}^{-1}\right)$ than that in the E2-treated groups at $48 \mathrm{~h}$. The results indicated that vitexin in low concentration range of $10^{-10}-10^{-6} \mu \mathrm{g} \mathrm{mL}^{-1}$ could promote

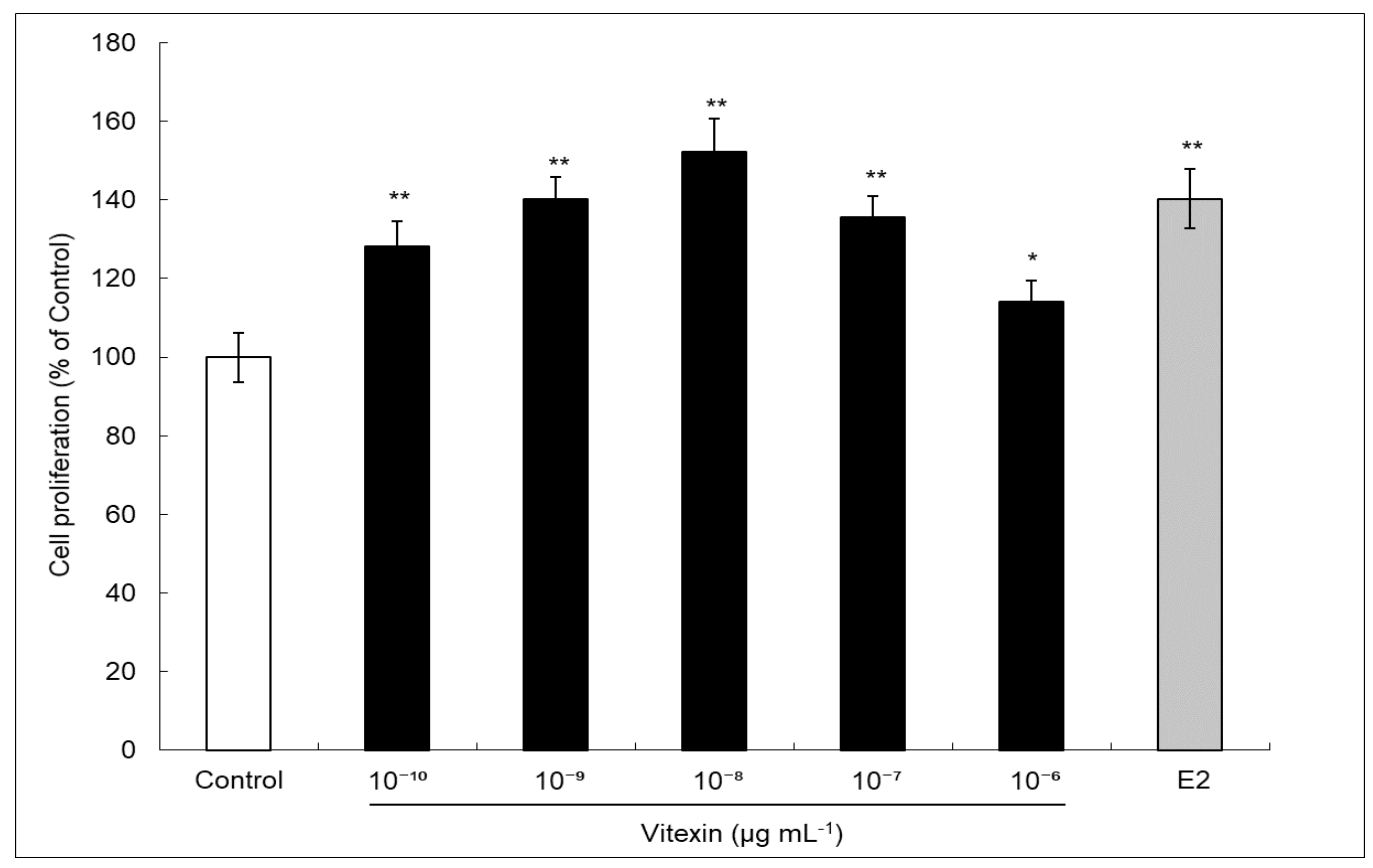

FIGURE 1. The effect of vitexin on the proliferation rate of MC3T3-E1 cells. The cells were cultured in the presence of vitexin $\left(10^{-10}-10^{-6} \mu \mathrm{g} \mathrm{mL}^{-1}\right)$ or E2 $\left(10^{-8} \mu \mathrm{g} \mathrm{mL}^{-1}\right)$ for 2 days. Cell viability was measured by the MTT assay. The results are expressed as a percentage of the control values, and each value is the mean \pm standard deviation; $\mathrm{n}=6 ;^{*} \mathrm{p}<0.05,^{* *} \mathrm{p}<0.01$ compared with the control group 
cell proliferation, but not in a concentration-dependent manner and it was non-toxic to the cells.

\section{EFFECT OF VITEXIN ON MC3T3-E1 CELL DIFFERENTIATION}

Alkaline phosphatase (ALP) is an early representative indicator of osteoblastic differentiation, which plays a crucial role in regulating mineralization of the bone matrix. Figure 2 shows the effect of vitexin on the differentiation of MC3T3-E1 cells by determining ALP activity in the cells. Compared with the control group, vitexin significantly promoted the ALP activity on day 5 at concentrations of $10^{-8}$ and $10^{-6} \mu \mathrm{g} \mathrm{mL}^{-1}(\mathrm{p}<0.01$ or $\mathrm{p}<0.05$ ), but did not increase the ALP activity at the

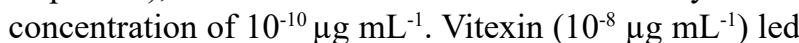
to the maximal effect on ALP activity on day 5, which enhanced the ALP activity by $24 \%$ in comparison to the control group. As a positive control, E2 $\left(10^{-8} \mu \mathrm{g} \mathrm{mL} \mathrm{m}^{-1}\right)$ also significantly enhanced ALP activity by $13 \%$ at day 5 $(\mathrm{p}<0.05)$ as compared to the control group. The simulative activity of vitexin $\left(10^{-8} \mu \mathrm{g} \mathrm{mL} \mathrm{m}^{-1}\right)$ on cell differentiation was stronger than that of E2 $\left(10^{-8} \mu \mathrm{g} \mathrm{mL}^{-1}\right)$. The results indicated that vitexin could promote osteoblastic cell differentiation.

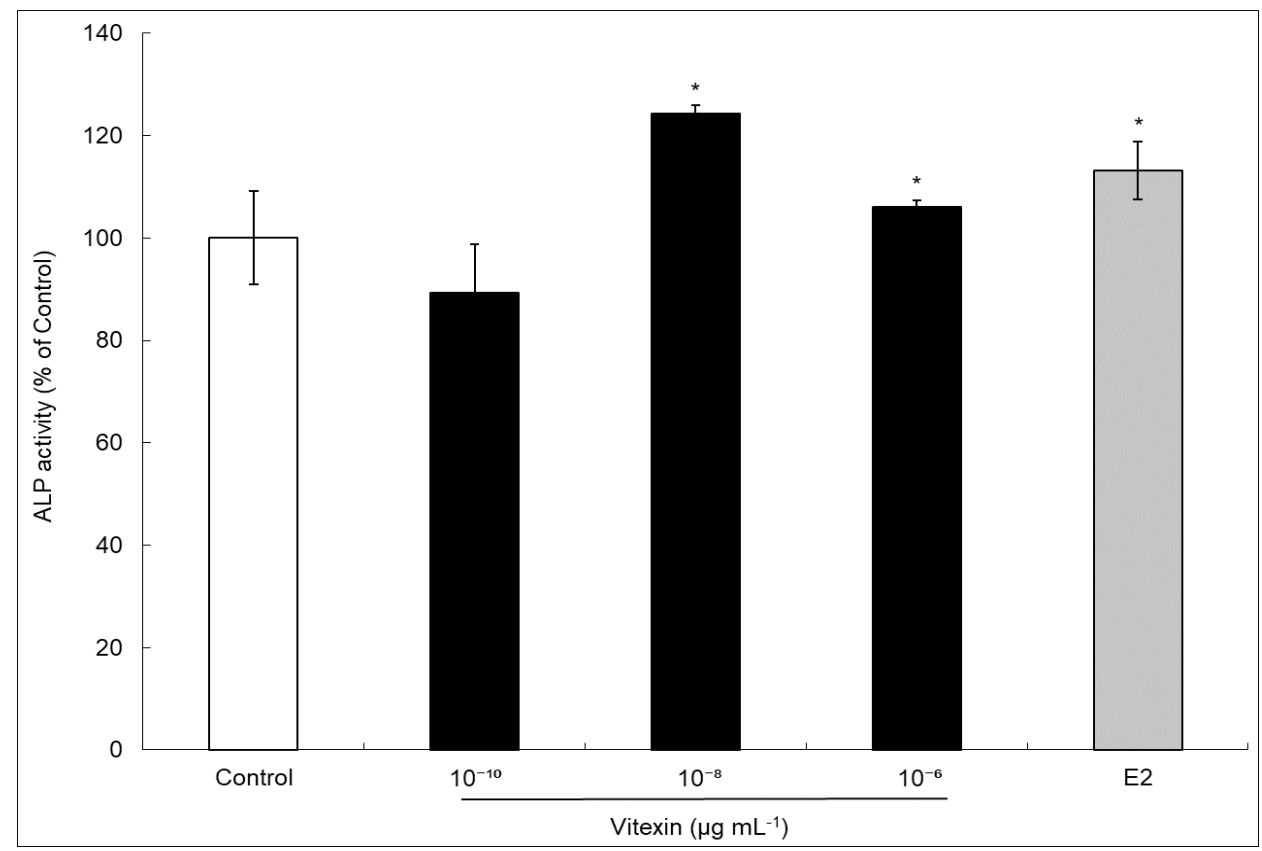

FIGURE 2. The effect of vitexin on ALP activity in MC3T3-E1 cells. The cells in 12-well plates were cultured with vitexin $\left(10^{-6}, 10^{-8}\right.$ and $\left.10^{-10} \mu \mathrm{g} \mathrm{mL}^{-1}\right)$ or E2 $\left(10^{-8} \mu \mathrm{g} \mathrm{mL} \mathrm{m}^{-1}\right.$ of $\mathrm{E} 2$ as a positive control) for 5 days. The results ware expressed as a percentage of the control values, and each value is the mean \pm standard deviation, $n=3 ;{ }^{*} \mathrm{p}<0.05$ compared with the control group

\section{EXPRESSION LEVELS OF OCN MRNA}

Osteocalcin $(\mathrm{OCN})$ is a late differentiation marker of osteoblast and regulates matrix mineralization during bone formation. As shown in Figure 3, the effect of vitexin on the expression level of OCN mRNA in MC3T3-E1 cells was examined by quantitative real-time PCR. Vitexin $\left(10^{-6}, 10^{-8}\right.$, and $\left.10^{-10} \mu \mathrm{g} \mathrm{mL} \mathrm{mL}^{-1}\right)$ significantly increased the expression level of OCN mRNA $(\mathrm{p}<0.01)$, which was respectively up-regulated by $3.1-, 5.8-$, and 4.2 -fold compared to the control group. Vitexin $\left(10^{-8} \mu \mathrm{g} \mathrm{mL}^{-1}\right)$ was found to give the maximal effect on the expression level of OCN mRNA at day 4. The OCN mRNA level was also significantly increased after E2 $\left(10^{-8} \mu \mathrm{g} \mathrm{mL}^{-1}\right)$ treatment $(\mathrm{p}<0.01)$, which was up-regulated by 3.5 - fold as compared to the level in the control group. However, the OCN mRNA expression levels after E2 $\left(10^{-8} \mu \mathrm{g}\right.$ $\mathrm{mL}^{-1}$ ) treatment is lower than those observed in vitexin $\left(10^{-8}\right.$ or $\left.10^{-10} \mu \mathrm{g} \mathrm{mL}^{-1}\right)$ treatment, but higher than those observed in vitexin $\left(10^{-6} \mu \mathrm{g} \mathrm{mL}^{-1}\right)$ treatment. 


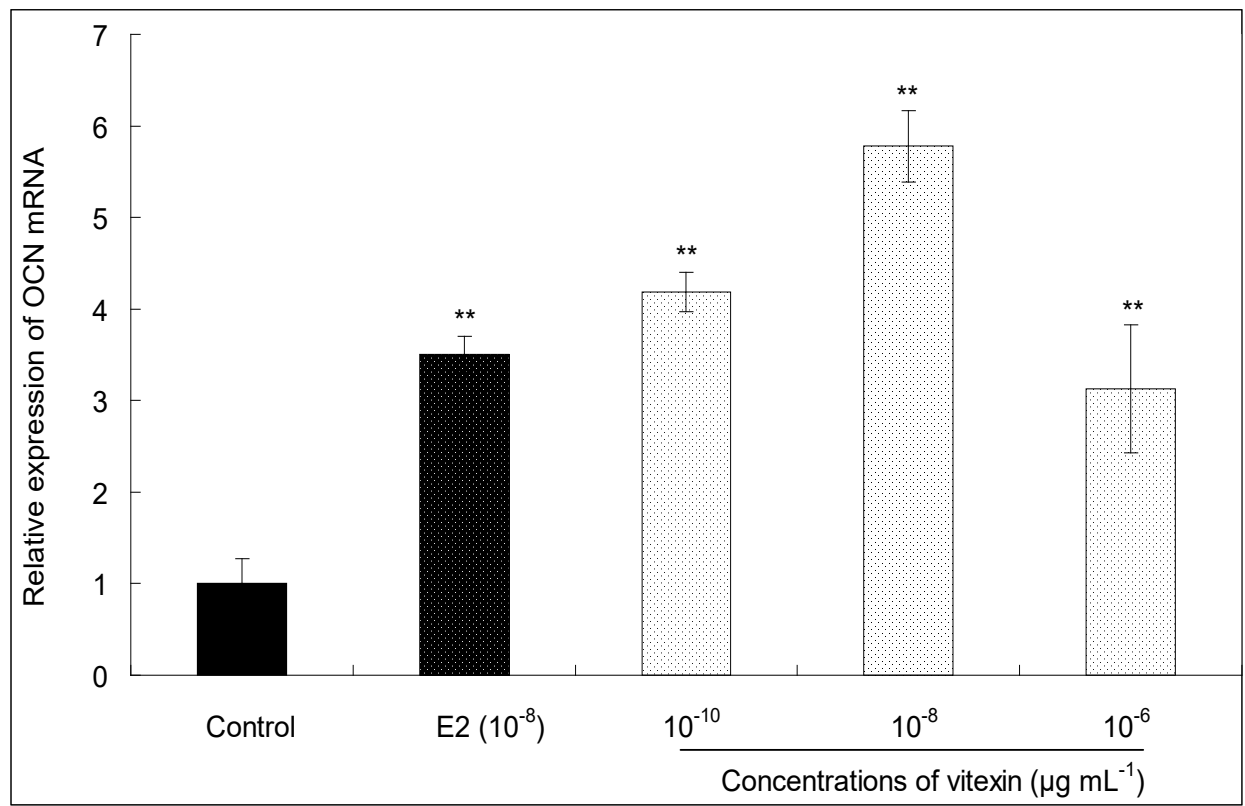

FIGURE 3. The effect of different concentrations of vitexin on the expression level of osteocalcin (OCN) mRNA. MC3T3-E1 cells in 12-well culture plates were cultured with various concentrations of vitexin (10 ${ }^{6}, 10^{-8}$, and $\left.10^{-10} \mu \mathrm{g} \mathrm{mL}{ }^{-1}\right)$ or E2 $\left(10^{-8} \mu \mathrm{g} \mathrm{mL}^{-1}\right)$ as a positive control for 4 days. The results were normalized by the mRNA level of GAPDH. Values are mean \pm standard deviation. All experiments were performed in triplicate. $* * \mathrm{p}<0.01 \mathrm{vs}$

\section{DETERMINATION OF THE INHIBITORY CONCENTRATION OF} DEX ON MC3T3-E1 CELLS

To determine the inhibitory concentration of DEX on MC3T3-E1 cells, the absorbance of DEX-treated cells was measured by MTT assay. Compared with the control group, DEX $\left(10^{-6}\right.$ and $\left.10^{-5} \mathrm{M}\right)$ treatment markedly inhibited cell growth $(\mathrm{p}<0.01)$, while DEX $\left(10^{-9}\right.$ and $10^{-8}$ $\mathrm{M})$ treatment greatly increased cell proliferation (Figure 4). In this study, the concentration of $10^{-6} \mathrm{M}$ was chosen as the inhibitory concentration of DEX on MC3T3-E1 cells and used for the proceeding experiments.

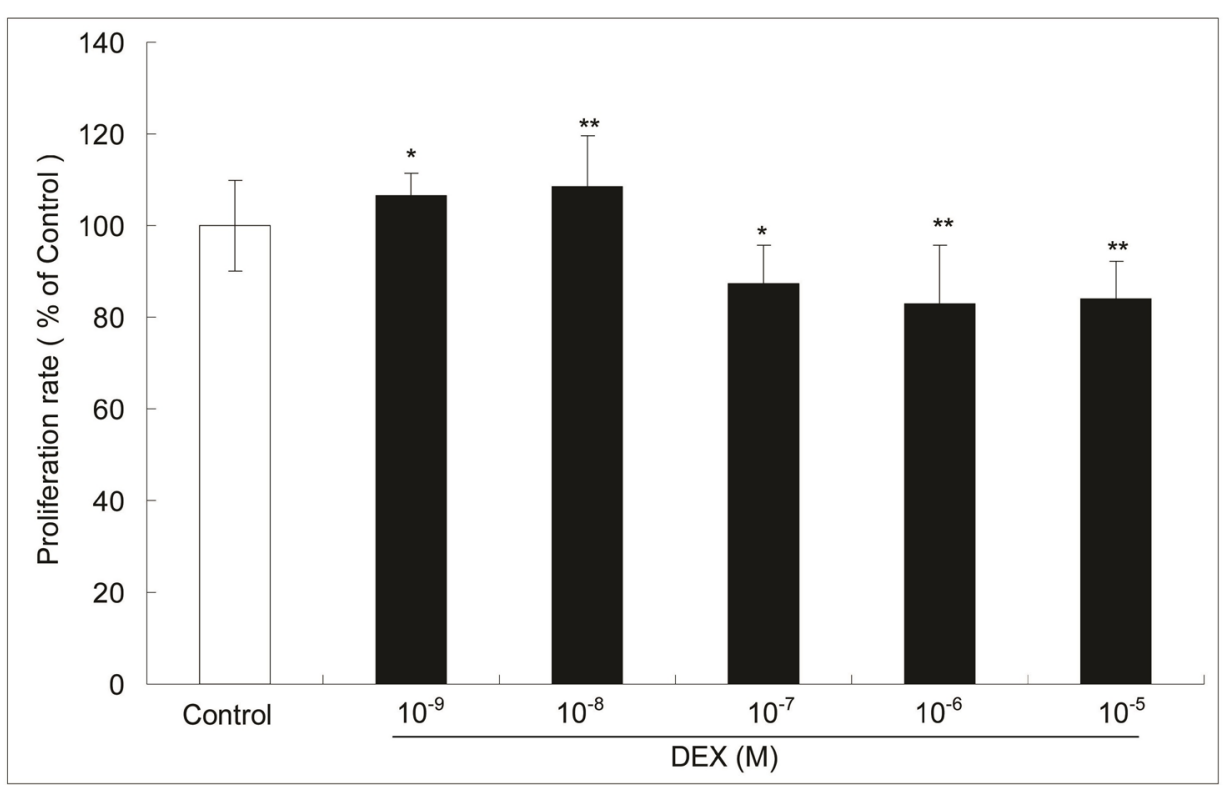

FIGURE 4. The effect of dexamethasone (DEX) on the viability of MC3T3-E1 cells. Cells were treated with DEX $\left(10^{-9}, 10^{-8}, 10^{-7}, 10^{-6}\right.$, and $\left.10^{-5} \mathrm{M}\right)$ for $48 \mathrm{~h}$. Treatment with DEX $\left(10^{-6}\right.$ and $\left.10^{-5} \mathrm{M}\right)$ decreased cell viability, which was determined using the MTT assay. ${ }^{*} \mathrm{p}<0.05$ compared with control. ${ }^{* *} \mathrm{p}<0.01$ compared with control 


\section{EFFECT OF VITEXIN ON DEX-INDUCED INHIBITION OF} OSTEOGENETIC DIFFERENTIATION

As shown in Figure 5, compared with the control group, there was a $69.49 \%, 9.87 \%$, and $24.64 \%$ decrease in ALP activity at day 3 in the DEX group, the DEX+vitexin group and the $\mathrm{DEX}+\mathrm{E} 2$ group, respectively. This indicated that DEX at $10^{-6} \mathrm{M}$ greatly suppressed the differentiation of cells, and very significant differences were observed between the control group and the DEX group at the assayed time point $(\mathrm{p}<0.01)$. While compared with the group treated with DEX alone, ALP activity was significantly increased in cells treated with a combination of DEX and vitexin $(p<0.01)$, which suggested that vitexin greatly alleviated the inhibitory effect on cell differentiation exerted by DEX. ALP activity was also significantly improved in the DEX+E2 group than that in the DEX group. However, the rescue effect of E2 $\left(10^{-8} \mu \mathrm{g} \mathrm{mL}^{-1}\right)$ on cell differentiation inhibited by DEX is weaker than that of vitexin $\left(10^{-8} \mu \mathrm{g}\right.$ $\left.\mathrm{mL}^{-1}\right)$.

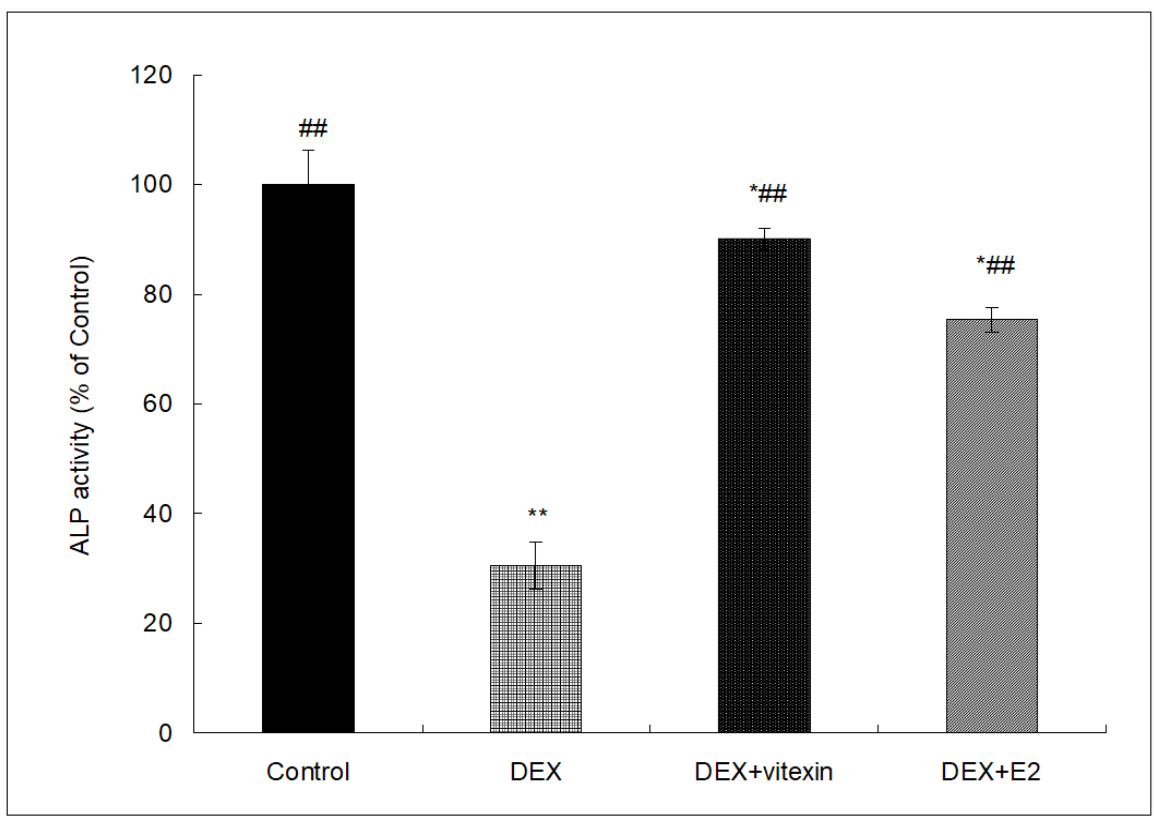

FIGURE 5. Effect of vitexin on dexamethasone (DEX)-suppressed ALP activity of MC3T3-E1. After 1-day preincubation with $10^{-6} \mathrm{M}$ DEX, cells were then treated with $10^{-8} \mu \mathrm{g} \mathrm{mL} \mathrm{L}^{-1}$ vitexin or $10^{-8} \mu \mathrm{g} \mathrm{mL}^{-1}$ of E2 for 3 days, and then ALP activity was determined. All experiments were performed in triplicate. ${ }^{*} \mathrm{p}<0.05$ and ${ }^{* *}$ $\mathrm{p}<0.01$ compared with the control group, \#\#p<0.01 compared with the DEX group

\section{EFFECT OF VITEXIN ON DEX-INDUCED INHIBITION OF MATRIX MINERALIZATION}

Von Kossa staining of mineralized nodules was found to reflect the degree of osteoblast maturity. Mineralized bone nodule formation is an osteoblast maturation marker (Niu et al. 2012). The effect of vitexin on mineralization in DEX-induced cells was determined by the Von Kossa method, which is frequently used to quantify mineralization in cell culture.

As observed in Figure 6, the visual differences were obvious between the control group and the other experimental groups, and far more mineral deposition was found in the control group than that in the DEX group, the DEX+vitexin group, and the DEX+E2 group. The results indicated DEX treatment caused a significant reduction in mineralized nodules in cells. However, following vitexin or E2 treatment, mineral deposition in DEX-pretreated cells was significantly increased than that in cells treated with DEX alone. These results demonstrated that treatment with vitexin or E2 could alleviate the inhibitory effect of DEX on calcium deposition in cells. 


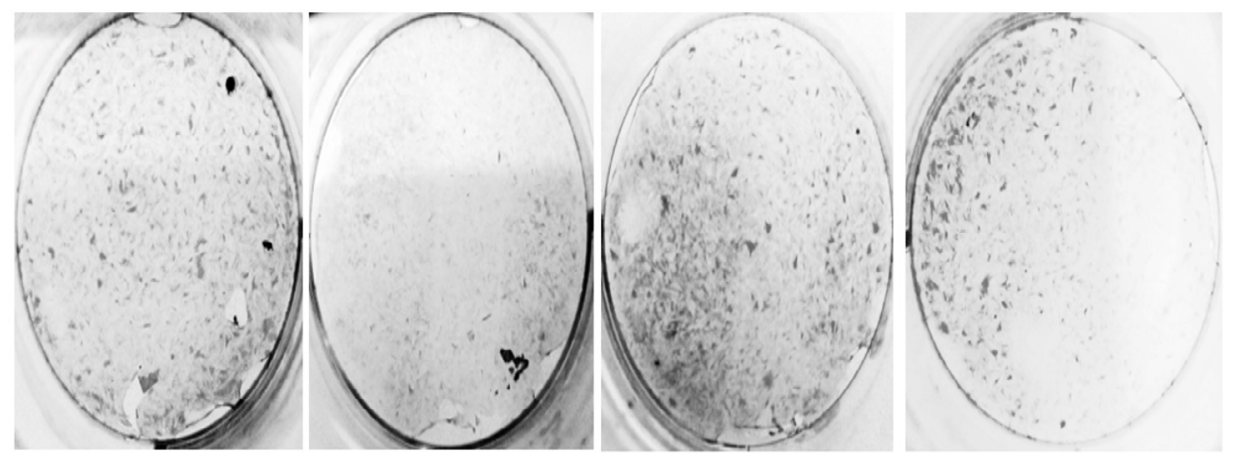

A

B

C

D

FIGURE 6. Representative images of Von Kossa-stained mineralized nodules formed after culture for 28 days (A: Control, B: DEX, C: DEX+vitexin $\left(10^{-8} \mu \mathrm{g} \mathrm{mL}^{-1}\right)$, D: DEX+E2 $\left(10^{-8} \mu \mathrm{g} \mathrm{mL}^{-1}\right)$

As observed in Figure 7, compared with the control group, there is a significant reduction of the mineralization level in the DEX group, the DEX+vitexin group, and the DEX+E2 group by $26.61,7.76$ and $11.31 \%$ $(\mathrm{p}<0.01$ or $\mathrm{p}<0.05)$, respectively. However, there is a significant elevation of the mineralization level in
$\mathrm{DEX}+$ vitexin group and $\mathrm{DEX}+\mathrm{E} 2$ group as compared to that in the DEX group $(\mathrm{p}<0.05)$, indicating that vitexin

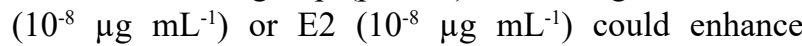
the mineralization level of cells inhibited by DEX. Moreover, vitexin showed a stronger alleviating effect on the mineralization level of DEX-inhibited cells than E2.

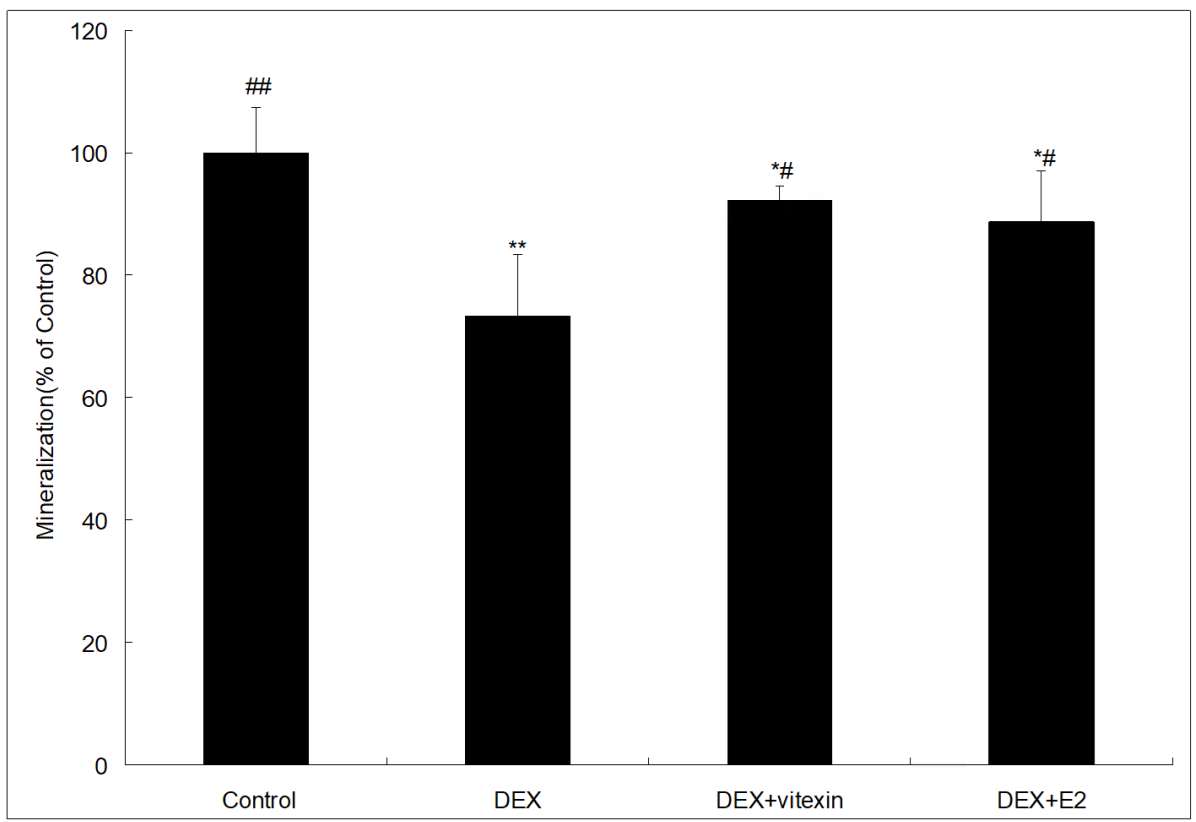

FIGURE 7. Effect of vitexin on mineralization on the extracellular matrix in MC3T3-E1 cells pretreated with dexamethasone (DEX). Cells in 6-well plates were cultured in a differentiation medium (a-MEM containing $10 \% \mathrm{FBS}, 10 \mathrm{mM} \beta$-glycerophosphate, and $50 \mu \mathrm{g} \mathrm{mL}^{-1}$ ascorbic acid) with $10^{-8} \mu \mathrm{g} \mathrm{mL}^{-1}$ of vitexin or $10^{-8} \mu \mathrm{g} \mathrm{mL}^{-1}$ of E2 as a positive control for 28 days. Values are expressed as mean \pm standard deviation of three independent experiments. ${ }^{*} p<0.05$ and ${ }^{* *} \mathrm{p}<0.01$ compared with the control group, $\# \# p<0.01$ compared with the DEX group 


\section{DISCUSSION}

Many chemical compounds derived from Chinese medicinal plants have been confirmed to fight osteoporosis or osteonecrosis (Che et al. 2016). Cajanus cajan leaves are an important drug in traditional Chinese medicine, and is used for reducing swellings, relieving pain, killing parasites, and treating aseptic necrosis of the femoral head and osteoporosis (Yuan et al. 2005; Zhang et al. 2010). C. cajan leaves are rich in flavonoids with a high pharmaceutical value and biomedical potential (Nix et al. 2015). Among them, vitexin, a natural C-glycosyl flavonoid with a variety of beneficial properties, is considered the principle active constituent in $C$. cajan leaves. An earlier study reported the effects of water crude extract of $C$. cajan leaves, in which the major constituents are total flavonoids and polysaccharide, on the osteogenic and adipogenic differentiation of mouse primary bone marrow stromal cells and the adipogenic trans-differentiation of mouse primary osteoblasts (Zhang et al. 2010). However, little information concerning the osteogenic activity of vitexin is available. Furthermore, the protective effect of vitexin against the attenuating effect of DEX on osteoblast differentiation and mineralization is also unknown to date.

The effect of vitexin on the differentiation of rat bone marrow mesenchymal stem cells was evaluated in a recent study (Zhou et al. 2014). However, it was reported that depending on the cell type and origin, bioactive compound might cause different effects on osteoblast differentiation (Arriero et al. 2012; Miron et al. 2013). To fully elucidate the osteogenic effect of vitexin and its related mechanism, the present study examined the direct effect of vitexin on the proliferation and differentiation of MC3T3-E1 cells.

Our results indicated that treatment with vitexin $\left(10^{-10}-10^{-6} \mu \mathrm{g} \mathrm{mL}^{-1}\right)$ greatly affected the cell viability of MC3T3-E1 cells, which suggested that vitexin could significantly enhance cell proliferation, in a concentration-independent manner, in the low concentration range, and that it holds no cytotoxicity to the cells. It has been proved that some flavonoids possessed potent biological activities even in low concentration range of $10^{-12}-10^{-15} \mathrm{~mol} \mathrm{~L}^{-1}$ (Chang et al. 2003). A dimmer of genistein, podocarnone, a flavonoid from Podocarpium podocarpum, was also reported to exhibit potent stimulatory effects on osteoblastic proliferation in the low concentration range of $10^{-12}$ to $10^{-14} \mathrm{~mol} \mathrm{~L}^{-1}$. Furthermore, the number of phenolic rings that contained in its structure may be related to the antiosteoporosis activity (Ma et al. 2013).

Furthermore, our data showed that vitexin at $10^{-8}$ and $10^{-6} \mu \mathrm{g} \mathrm{mL}^{-1}$ significantly increased ALP activity, suggesting that vitexin could accelerate the differentiation of MC3T3-E1 cells in the low concentration range.

Osteocalcin $(\mathrm{OCN})$ is one of the most commonly used markers for mature osteoblasts. We observed an evident elevation in the expression of OCN mRNA in the vitexin-treated MC3T3-E1 cells and further confirmed the stimulatory effect of vitexin on osteoblast differentiation.

It has been demonstrated that high-concentration glucocorticoids (GCs) inhibit bone growth, and that DEX decreased ALP activity in MC3T3-E1 cells (Canalis \& Delany 2002; Lin et al. 2017). However, in this work, in the presence of vitexin, such inhibition was alleviated, which suggested that vitexin could attenuate osteogenic differentiation and mineralization impairment induced by DEX to some degree.

In previous studies, GCs were viewed as an oxidant stimulus to which oxidative stress is a susceptive response in skeletal tissue. GCs were reported to cause ROS-induced apoptosis of osteoblasts in bone and decrease mineral deposition in vitro (Feng \& Tang 2014).

In this study, dexamethasone (DEX) at $10^{-6} \mathrm{M}$ was demonstrated to greatly decrease ALP activities and the formation of mineralized nodules in MC3T3-E1 cells. As little information is available regarding the effects of vitexin on the differentiation and mineralization of osteoblastic cells under GCs stimulation, we probed the effect of vitexin on inhibition of DEX-induced osteoblast cell differentiation and mineralization in the current study. Our results showed vitexin could alleviate DEX-induced inhibition of osteogenic differentiation in MC3T3-E1 cells. In addition, vitexin increased osteoblast mineralization in DEX-inhibited MC3T3-E1 cells. The data of this study demonstrated that vitexin has an in vitro anti-osteoporosis effect and may offer some potential in the management of glucocorticoidinduced osteoporosis.

Recent evidence from several studies has suggested that oxidative stress may lead to osteoporosis by altering the function of osteoclast and osteoblast (Hessle et al. 2002; Lee et al. 2005; Luo et al. 2016; Marie \& Kassem 2011). Some natural antioxidant compounds like genistein, vitamin $\mathrm{E}$, and vitamin $\mathrm{C}$ were demonstrated to prevent bone loss by protecting against the oxidative damage of free radicals in MC3T3-E1 OB cells, in addition to stimulating their proliferation. A recent report further demonstrated that tanshinol with polyphenolic hydroxyl groups in the structure stimulated bone formation, exerted the inhibitory action on oxidative stress (Luo et al. 2016). A prior study showed that the antioxidant activity of vitexin is attributed to the characteristics of the hydroxyl groups at the 4' position of the B-ring and the $7^{\prime}$ position of the A-ring (Zhang et 
al. 2014). The good antioxidant capacity of vitexin may play an important role in its osteogenic activity.

Glucocorticoids were recently reported to affect the Wnt signaling pathway in osteoblasts (Komori 2016). In addition, flavonoids were demonstrated to induce differentiation of cultured osteoblasts via the activation of the Wnt signaling pathway (Guo et al. 2011; Nash et al. 2015). In this study, we presented the preliminary results showing that vitexin significantly stimulated cell proliferation and osteogenic differentiation in the murine pre-osteoblastic cell line MC3T3-E1, and attenuated dexamethasone (DEX)-induced inhibition of differentiation and mineralization of MC3T3-E1 cells. However, the detailed mechanism by which vitexin plays these roles remains unclear. The possible role of vitexin on the Wnt signaling pathway and its detailed mechanism of action in inducing osteogenesis requires further study.

\section{CONCLUSION}

The present study demonstrated that vitexin could significantly promote cell proliferation and osteogenic differentiation in MC3T3-E1 cells, and attenuate dexamethasone (DEX)-induced inhibition of differentiation and mineralization of MC3T3-E1 cells. These findings suggested that vitexin may be considered a promising therapeutic agent in the prevention of bone disease and plays an important role in the prevention of glucocorticoid-induced osteoporosis.

\section{ACKNOWLEDGEMENTS}

This research was supported by the open project of Northeast Agricultural University/Key Laboratory of Agricultural Microbiology of Heilongjiang Provincial Science and Technology Department, P.R. China (No. NW2017005), Natural Science Foundation of Heilongjiang Province of P.R. China (No. C2017021, No. C2017004) and Heilongjiang Touyan Innovation Team Program (Tree Genetics and Breeding Innovation Team).

\section{REFERENCES}

Adami, G. \& Saag, K.G. 2019. Glucocorticoid-induced osteoporosis update. Current Opinion in Rheumatology 31(4): 388-393.

Adler, R.A. 2019. Glucocorticoid-induced osteoporosis: Management challenges in older patients. Journal of Clinical Densitometry 22(1): 20-24.

Arriero Mdel, M., Ramis, J.M., Perello, J. \& Monjo, M. 2012. Differential response of MC3T3-E1 and human mesenchymal stem cells to inositol hexakisphosphate. Cellular Physiology and Biochemistry 30: 974-986.

Balasubramanian, A., Wade, S.W., Adler, R.A., Saag, K., Pannacciulli, N. \& Curtis, J.R. 2018. Glucocorticoid exposure and fracture risk in a cohort of US patients with selected conditions. Journal of Bone and Mineral Research 33: 1881-1888.

Bolognese, M.A. 2010. SERMs and SERMs with estrogen for postmenopausal osteoporosis. Reviews in Endocrine and Metabolic Disorders 11(4): 253-259.

Canalis, E. 2003. Mechanisms of glucocorticoid-induced osteoporosis. Current Opinion in Rheumatology 15(4): 454-457.

Canalis, E. \& Delany, A.M. 2002. Mechanisms of glucocorticoid action in bone. Annals of the New York Academy of Sciences 966: 73-81.

Caplan, A., Fett, N., Rosenbach, M., Werth, V.P. \& Micheletti, R.G. 2017. Prevention and management of glucocorticoidinduced side effects: A comprehensive review: Ocular, cardiovascular, muscular, and psychiatric side effects and issues unique to pediatric patients. Journal of the American Academy of Dermatology 76: 201-207.

Chang, E.J., Lee, W.J., Cho, S.H. \& Choi, S.W. 2003. Proliferative effects of flavan-3-ols and propelargonidins from rhizomes of Drynaria fortunei on MCF-7 and osteoblastic cells. Archives of Pharmacal Research 26: 620-630.

Che, C.T., Wong, M.S. \& Lam, C.W. 2016. Natural products from Chinese medicines with potential benefits to bone health. Molecules 21(3): 239.

Chen, J.S. \& Sambrook, P.N. 2012. Antiresorptive therapies for osteoporosis: A clinical overview. Nature Reviews Endocrinology 8: 81-91.

Chen, L.R., Wen, Y.T., Kuo, C.L. \& Chen, K.H. 2014. Calcium and vitamin D supplementation on bone health: Current evidence and recommendations. International Journal of Gerontology 8(4): 183-188.

Dong, L.Y., Fan, Y.F., Shao, X. \& Chen, Z.W. 2011. Vitexin protects against myocardial ischemia/reperfusion injury in Langendorff-perfused rat hearts by attenuating inflammatory response and apoptosis. Food and Chemical Toxicology 49: 3211-3216.

Feng, Y.L. \& Tang, X.L. 2014. Effect of glucocorticoidinduced oxidative stress on the expression of Cbfa1. Chemico-Biological Interactions 207: 26-31.

Fu, Y., Zu, Y., Liu, W., Hou, C., Chen, L., Li, S., Shi, X. \& Tong, M. 2007. Preparative separation of vitexin and isovitexin from pigeonpea extracts with macroporous resins. Journal of Chromatography A 1139: 206-213.

Gu, C.B., Liu, Z.Z., Yuan, X.H., Li, W., Zu, Y.Z. \& Fu, Y.Y. 2017. Preparation of vitexin nanoparticles by combining the antisolvent precipitation and high pressure homogenization approaches followed by lyophilization for dissolution rate enhancement. Molecules 22(12): 2038.

Guanabens, N., Gifre, L. \& Peris, P. 2014. The role of Wnt signaling and sclerostin in the pathogenesis of glucocorticoid-induced osteoporosis. Current Osteoporosis Reports 12: 90-97.

Guo, A.J., Choi, R.C., Cheung, A.W., Chen, V.P., Xu, S.L., Dong, T.T., Chen, J.J. \& Tsim, K.W. 2011. Baicalin, a flavone, induces the differentiation of cultured osteoblasts: An action via the Wnt/beta-catenin signaling pathway. Journal of Biological Chemistry 286(32): 27882-27893. 
Hadji, P. 2012. The evolution of selective estrogen receptor modulators in osteoporosis therapy. Climacteric 15(6): 513-523.

He, M., Min, J.W., Kong, W.L., He, X.H., Li, J.X. \& Peng, B.W. 2016. A review on the pharmacological effects of vitexin and isovitexin. Fitoterapia 115: 74-85.

Hessle, L., Johnson, K.A., Anderson, H.C., Narisawa, S., Sali, A., Goding, J.W., Terkeltaub, R. \& Millan, J.L. 2002. Tissue-nonspecific alkaline phosphatase and plasma cell membrane glycoprotein- 1 are central antagonistic regulators of bone mineralization. Proceedings of the National Academy of Sciences of the United States of America 99: 9445-9449.

Kim, J.H., Lee, B.C., Kim, J.H., Sim, G.S., Lee, D.H., Lee, K.E., Yun, Y.P. \& Pyo, H.B. 2005. The isolation and antioxidative effects of vitexin from Acer palmatum. Archives of Pharmacal Research 28(2): 195-202.

Komori, T. 2016. Glucocorticoid signaling and bone biology. Hormone and Metabolic Research 48(11): 755-763.

Kulak Júnior J., Kulak, C.A. \& Taylor, H.S. 2010. SERMs in the prevention and treatment of postmenopausal osteoporosis: An update. Arquivos Brasileiros de Endocrinologia \& Metabologia 54(2): 200-205.

Lee, N.K., Choi, Y.G., Baik, J.Y., Han, S.Y., Jeong, D.W., Bae, Y.S., Kim, N. \& Lee, S.Y. 2005. A crucial role for reactive oxygen species in RANKL-induced osteoclast differentiation. Blood 106: 852-859.

Lin, Z., Jiang, Z.L., Chen, L.H., Sun, Y., Chen, S.Z., Zhou, P., Xia, A.X., Jin, H., Zhu, Y.W. \& Chen, D.Y. 2017. Glucocorticoid-induced leucine zipper may play an important role in icariin by suppressing osteogenesis inhibition induced by glucocorticoids in osteoblasts. Biomedicine \& Pharmacotherapy 90: 237-243.

Luo, S., Yang, Y., Chen, J., Zhong, Z., Huang, H., Zhang, J. \& Cui, L. 2016. Tanshinol stimulates bone formation and attenuates dexamethasone-induced inhibition of osteogenesis in larval zebrafish. Journal of Orthopaedic Translation 4: 35-45.

Ma, X.Q., Zheng, C.J., Zhang, Y., Hu, C.L., Lin, B., Fu, X.Y., Han, L.Y., Xu, L.S., Rahman, K. \& Qin, L.P. 2013. Antiosteoporotic flavonoids from Podocarpium: Podocarpum. Phytochemistry Letters 6: 118-122.

Marie, P.J. \& Kassem, M. 2011. Osteoblasts in osteoporosis: Past, emerging, and future anabolic targets. European Journal of Endocrinology 165: 1-10.

Miron, R.J., Caluseru, O.M., Guillemette, V., Zhang, Y., Gemperli, A.C., Chandad, F. \& Sculean, A. 2013. Influence of enamel matrix derivative on cells at different maturation stages of differentiation. PloS ONE 8: e71008.

Nash, L.A., Sullivan, P.J., Peters, S.J. \& Ward, W.E. 2015. Rooibos flavonoids, orientin and luteolin, stimulate mineralization in human osteoblasts through the Wnt pathway. Molecular Nutrition \& Food Research 59(3): 443-453.

Niu, Y.B., Li, Y.H., Kong, X.H., Zhang, R., Sun, Y., Li, Q., Li, C., Liu, L., Wang, J. \& Mei, Q.B. 2012. The beneficial effect of Radix Dipsaci total saponins on bone metabolism in vitro and in vivo and the possible mechanisms of action. Osteoporosis International 23: 2649-2660.

Nix, A., Paull, C.A. \& Colgrave, M. 2015. The flavonoid profile of pigeonpea, Cajanus cajan: A review. Springerplus 4: 125.

Pereira, R.M., Carvalho, J.F., Paula, A.P., Zerbini, C., Domiciano, D.S., Goncalves, H., Danowski, J.S., Marques Neto, J.F., Mendonca, L.M., Bezerra, M.C., Terreri, M.T., Imamura, M., Weingrill, P., Plapler, P.G., Radominski, S., Tourinho, T., Szejnfeld, V.L. \& Andrada, N.C. 2012. Guidelines for the prevention and treatment of glucocorticoid-induced osteoporosis. Revista Brasileira De Reumatologia 52(4): 580-593.

Ponnapakkam, T., Katikaneni, R., Sakon, J., Stratford, R. \& Gensure, R.C. 2014. Treating osteoporosis by targeting parathyroid hormone to bone. Drug Discovery Today 19(3): 204-208.

Prabhakar, M.C., Bano, H., Kumar, I., Shamsi, M.A. \& Khan, M.S. 1981. Pharmacological investigations on vitexin. Planta Medica 43: 396-403.

Wang, W.Z., Olson, D., Cheng, B., Guo, X. \& Wang, K.Z. 2012. Sanguis Draconis resin stimulates osteoblast alkaline phosphatase activity and mineralization in MC3T3-E1 cells. Journal of Ethnopharmacology 142(1): 168-174.

Weinstein, R.S. 2011. Glucocorticoid-induced bone disease. New England Journal of Medicine 365: 62-70.

Wu, Z., Yan, D., Xie, Z., Weng, S., Zhou, Q., Li, H., Bai, B., Boodhun, V., Shen, Z., Tang, J. \& Yang, L. 2018. Combined treatment with cinnamaldehyde and PTH enhances the therapeutic effect on glucocorticoid-induced osteoporosis through inhibiting osteoclastogenesis and promoting osteoblastogenesis. Biochemical and Biophysical Research Communications 505: 945-950.

Yuan, J., Lin, J., Xu, C., Ye, Q., Xiong, Y., Huang, L. \& Yuan, H. 2005. Experimental research on prevention of glucocorticoid-induced avascular necrosis of the femoral head with Tongluo Shenggu capsule. Traditional Chinese Drug Research and Clinical Plarmacology 16: 185-188.

Zaheer, S., LeBoff, M. \& Lewiecki, E.M. 2015. Denosumab for the treatment of osteoporosis. Expert Opinion on Drug Metabolism \& Toxicology 11(3): 461-470.

Zhang, J., Liu, C., Sun, J., Liu, D. \& Wang, P. 2010. Effects of water extract of Cajanus cajan leaves on the osteogenic and adipogenic differentiation of mouse primary bone marrow stromal cells and the adipocytic trans-differentiation of mouse primary osteoblasts. Pharmaceutical Biology 48: 89-95.

Zhang, Y.J., Wang, D.M., Yang, L.N., Zhou, D. \& Zhang, J.F. 2014. Purification and characterization of flavonoids from the leaves of Zanthoxylum bungeanum and correlation between their structure and antioxidant activity. PloS ONE 9: e105725.

Zhou, C.H., Zhang, X. \& Xu, D.H. 2014. Effect of vitexin on the osteogenic differentiation of rat bone marrow mesenchymal stem cells. Chinese Journal of Modern Drug Application 31(4): 405-408 
Xiaohan Yuan \& Chengbo Gu*

Key Laboratory of Agricultural Microbiology of

Heilongjiang Provincial Science and Technology Department

Northeast Agricultural University

Harbin, 150030

China

Haiyan Han, Qiuxue Wang, Peijia Tang, Zhihui Zhang, Yujie Fu \& Chengbo $\mathrm{Gu}^{*}$

Key Laboratory of Forest Plant Ecology

Ministry of Education

Northeast Forestry University

Harbin, 150040

China

\section{Zhaohui Luo}

Fankou Lead-Zinc Mine Staff Hospital

Shenzhen Zhongjin Lingnan Nonfemet Company Limited Renhua, 512325

China

*Corresponding author; email: dilisatis@163.com

Received: 17 September 2019

Accepted: 14 February 2020 